DOI https://doi.org/10.30525/978-9934-26-007-0-3

\title{
ТРАНСФОРМАЦІЯ СИСТЕМИ СОЦАЛЬНОГО ЗАБЕЗПЕЧЕННЯ УКРАЇНИ ПІД ВПЛИВОМ COVID-19
}

\author{
Боднарук М. І., Бурка А. В.
}

\section{ВСТУП}

Світова пандемія коронавірусної хвороби (далі - COVID-19) стала глобальною проблемою 2020 року та змусила всі країни в найкоротші строки вносити зміни й обирати нові вектори розвитку економіки, систем соціального забезпечення, охорони здоров'я та освіти. Першочерговим завданням для всіх держав стало розроблення низки заходів, спрямованих на превенцію та протидію COVID-19.

Позитивним наслідком світової пандемії, як би це дивно не звучало, $€$ те, що кожна 3 країн майже одразу відчула, наскільки сильною та збалансованою є іiі економіка, наскільки високий рівень соціального забезпечення вона може надати своїм громадянам у кризовий період, наскільки злагоджено функціонують системи освіти, транспорту тощо. Найбільш гостро відчули на собі наслідки пандемії ті країни, у яких лише розпочався процес реформування медицини, освіти, економіки, системи соціального забезпечення, до таких країн можна зарахувати й Україну, адже надзвичайно важко переживати час кризи, коли «старі системи» вже майже зруйновані, а нові лише запроваджуються.

Однією з провідних систем, що знаходиться на «передовій» у боротьбі із COVID-19, є система соціального забезпечення кожної країни. У період пандемії найважливішими іiї завданнями $є$ підтримка доходів у тих, у кого вони зменшилися або практично відсутні; зняття бар'єрів і розширення доступу до соціальних програм і пільг, а саме внесення змін до порядку їх отримання, виходячи із існуючої епідеміологічної ситуації; адаптація системи в цілому до нових умов.

Уряди різних держав реагують на нові виклики по-різному. Деякі з них працюють над збереженням робочих місць, інші держави розширюють доступ до оплачуваних лікарняних, а також забезпечують додаткову допомогу, у тому числі фінансову, по догляду за дітьми для працюючих батьків, надають підтримку самозайнятим особам, безробітнім, пенсіонерам тощо.

Політика Уряду України не стала винятком, адже за період існування карантинних обмежень (з березня 2020 року й до цього часу) унесено чимало змін у нормативно-правове регулювання вітчизняної системи соціального забезпечення 3 метою підтримки тієї частини населення, що найбільше відчула на собі вплив світової пандемії. Виходячи 3 вищезазначеного, існує необхідність здійснити аналіз унесених змін і надати їм об'єктивну правову оцінку. 


\section{1. Соціальне забезпечення безробітних, пенсіонерів і сплата сдиного соціального внеску під час дії карантинних обмежень}

Законом України «Про внесення змін до Податкового кодексу України та інших законів України щодо підтримки платників податків на період здійснення заходів, спрямованих на запобігання виникненню і поширенню коронавірусної хвороби (COVID-19)» від 1 березня 2020 року № 533-IX ${ }^{1}$ унесено зміни до Закону України «Про збір та облік єдиного внеску на загальнообов'язкове державне соціальне страхування», а саме надано право фізичним особам-підприємцям, у тому числі й тим, які обрали спрощену систему оподаткування; особам, які провадять незалежну професійну діяльність чи іншу подібну діяльність та отримують дохід від цієї діяльності; членам фермерського господарства, якщо вони не належать до осіб, які підлягають страхуванню на інших підставах, тимчасово не сплачувати за себе єдиний соціальний внесок (далі - ССВ) за періоди з 1 березня по 30 квітня 2020 року. Дещо пізніше дію так званого «пільгового періоду» продовжено до 31 травня 2020 року².

Окрім цього, розглядалося питання про продовження «пільгового періоду» до 30 червня 2020 року включно, проте станом на сьогодні Проект Закону від 9 липня 2020 року № 3824 так і не ухвалено ³. На противагу цьому, прийнято Закон України «Про внесення змін до Закону України «Про збір та облік єдиного внеску на загальнообов'язкове державне соціальне страхування» від 13 травня 2020 року № 592-IX, відповідно до якого 3 1 січня 2021 року самозайняті особи, фізичні особи-підприємці, які мають основне місце роботи, звільняються від сплати за себе ЄСВ за місяці, за які роботодавець сплатив страховий внесок за них, не менше мінімального розміру; скасовується обов'язок фізичних осіб-підприємців (крім тих, які обрали спрощену систему оподаткування), осіб, які провадять незалежну професійну діяльність, і членів фермерського господарства сплачувати мінімальний розмір ЄСВ за місяці, у яких не отримано доходу ${ }^{4}$.

\footnotetext{
1 Про внесення змін до Податкового кодексу України та інших законів України щодо підтримки платників податків на період здійснення заходів, спрямованих на запобігання виникненню і поширенню коронавірусної хвороби (COVID-19) : Закон України від 17 березня 2020 р. № 533-IX / Верховна Рада України. URL: https://zakon.rada.gov.ua/laws/show/533-20\#Text (дата звернення: 18.11.2020).

2 Про внесення змін до Податкового кодексу України та інших законів України щодо додаткової підтримки платників податків на період здійснення заходів, спрямованих на запобігання виникненню i поширенню коронавірусної хвороби (COVID-19) : Закон України від 13 травня 2020 р. № 591-IX / Верховна Рада України. URL: https://zakon.rada.gov.ua/laws/show/591-20\#Техt (дата звернення: 18.11.2020).

3 Про внесення змін до деяких законодавчих актів України щодо додаткової підтримки платників податків на період здійснення заходів, спрямованих на запобігання виникнення i поширення коронавірусної хвороби (COVID-19) : Проект Закону України від 9 липня 2020 р. № 3824 / Верховна Рада України. URL: http://w1.c1.rada.gov.ua/pls/zweb2/webproc4_1?pf3511=69423 (дата звернення: 19.11.2020).

4 Про внесення змін до Закону України «Про збір та облік єдиного внеску на загальнообов'язкове державне соціальне страхування : Закон України від 13 травня 2020 р. № 592-IX / Верховна Рада України. URL: https://zakon.rada.gov.ua/laws/show/592-20\#Text (дата звернення: 19.11.2020).
} 
Унесення вищезазначених змін щодо порядку сплати $\mathrm{CCB}$, на нашу думку, потрібно розглядати з позиції платників ССВ та з позиції Фонду соціального страхування України (далі - Фонд) і Пенсійного фонду України.

Упроваджуючи навесні тимчасові суворі карантинні обмеження, Уряд України передбачав, що карантин 3 часом буде послаблюватися, що призведе до поступового відновлення економіки та повернення до «звичного» процесу надходження коштів до Фонду й Пенсійного фонду, унаслідок чого зменшиться кількість бюджетних видатків, які додатково спрямовувалися для забезпечення реалізації окремих заходів із соціальної підтримки населення.

Проте впроваджені тимчасові карантинні обмеження, виявилися далеко не тимчасовими, унаслідок чого в країні виникла так звана «система замкнутого кола»: 1) упроваджені Урядом України карантинні обмеження 3 метою зменшення поширення COVID-19 ігноруються 3 боку малого, середнього та великого бізнесу; 2) оскільки останні не можуть припинити свою роботу, бо для них це означатиме фактично припинення діяльності; 3) сплачувати податки, внески та заробітну плату не буде 3 чого; 4) а на суттєву підтримку від держави не варто розраховувати, оскільки дефіцит державного бюджету й так щоразу збільшується; 5) значною мірою й тому, що велика частина бюджетних коштів спрямовується на потреби Фонду та Пенсійного Фонду, які за «ідеальних» умов мали б здійснювати страхові виплати, допомоги за рахунок власних коштів, проте внаслідок різкого збільшення на них фінансового навантаження не в змозі це зробити самостійно.

Так, безумовно, у період пандемії, коли велика частина малого та середнього бізнесу змушена фактично призупиняти свою діяльність чи працювати з певними обмеженнями, вона значно втрачає в доходах, а тому потребує підтримки від держави, бодай у вигляді несплати протягом певного періоду ЄСВ. Проте з позиції Фонду та Пенсійного фонду несплата ЄСВ означає втрату їх основних доходів, це при тому, що в період пандемії зростає частка страхових виплат у зв'язку з тимчасовою втратою працездатності, стійкою втратою працездатності, смертю застрахованих осіб, у зв'язку з безробіттям, необхідністю підвищення пенсійних виплат тощо.

Окремі зміни відбулися й у системі пенсійного забезпечення, проте не всі вони пов'язані 3 пандемією COVID-19, частина 3 них має на меті підвищення матеріального забезпечення пенсіонерів загалом.

Так, із 1 квітня 2020 року особи, які отримують пенсію та яким виповнилося 80 років і більше, у яких щомісячний розмір пенсійних виплат не досягає розміру середньої заробітної плати (доходу) в Україні, 
отримують щомісячну компенсаційну виплату в розмірі до 500 гривень. Передбачається, що така доплата буде здійснюватися на постійній основі ${ }^{5}$.

Підвищення пенсійних виплат для окремих категорій осіб Уряд планує здійснювати й у 2021 році, про що свідчить постанова КМУ «Деякі питання підвищення пенсійних виплат для окремих категорій осіб у 2021 році та в подальшому» ${ }^{6}$ від 16 вересня 2020 року № 849. Так, із 1 липня 2021 року особи, яким виповнилося 75 років, до досягнення 80-річного віку, у яких щомісячний розмір пенсійних виплат не досягає розміру середньої заробітної плати (доходу) в Україні, будуть отримувати щомісячну компенсаційну виплату в розмірі до 400 гривень.

3 метою матеріальної підтримки окремих категорій населення в період дії карантинних обмежень здійснено виплату одноразової допомоги в сумі 1000 гривень окремим категоріям населення (перелік яких зазначено в Постанові КМУ від 1 квітня 2020 року № 251).

Необхідно зазначити, що фінансування всіх вищезазначених одноразових допомог, компенсаційних виплат, у тому числі й витрат на індексацію пенсійних виплат у 2020-2021 роках здійснювалося/буде здійснюватися за рахунок коштів державного бюджету.

У період дії карантинних обмежень важливим також $є$ питання соціального забезпечення безробітних осіб, кількість яких в Україні та загалом у світі протягом останнього року невпинно продовжує зростати.

За даними Державної служби статистики України, кількість зайнятого населення у віці 15-70 років у I півріччі 2020 року порівняно з I півріччям 2019 року скоротилася на 430 тис. осіб і становила 16,1 млн осіб. Із 12 березня по 31 жовтня 2020 року розпочато виплату допомоги по безробіттю 482 тис. безробітним, що майже вдвічі більше ніж за аналогічний період минулого року ${ }^{7}$.

3 метою підвищення рівня соціального забезпечення безробітних в Україні: 1) підвищено мінімальний розмір допомоги по безробіттю на період карантину та протягом 30 календарних днів після його закінчення з 650 гривень до

\footnotetext{
5 Деякі питання підвищення пенсійних виплат і надання соціальної підтримки окремим категоріям населення у 2020 році : Постанова Кабінету Міністрів України від 1 квітня 2020 р. № 251. База даних «Законодавство Украӥни». URL: https://www.kmu.gov.ua/npas/deyaki-pitannya-pidvishchennya-pensijnih-viplat-inadannya-socialnoyi-pidtrimki-okremim-kategoriyam-naselennya-u-2020-roci-i010420-251 (дата звернення: 19.11.2020).

${ }^{6}$ Деякі питання підвищення пенсійних виплат для окремих категорій осіб у 2021 році та в подальшому : Постанова Кабінету Міністрів України від 16 вересня 2020 р. № 849. База даних «Законодавство Украӥни». URL: https://www.kmu.gov.ua/npas/deyaki-pitannya-pidvishchennya-pensijnih-viplat-dlya-okremih-kategorij-osib-u2021-roci-ta-v-podalshomu-i160920-849 (дата звернення: 20.11.2020).

${ }^{7}$ Ситуація на ринку праці та діяльність Державної служби зайнятості у січні-жовтні 2020 року. Офіційний сайт Державної служби зайнятості. URL: https://www.dcz.gov.ua/analitics/67 (дата звернення: 23.11.2020).
} 
1000 гривень $^{8}$ (максимальний із 1 липня 2020 року не може перевищувати 8788 тис. гривень, а 31 грудня 2020 року - 9080 тис. гривень) ${ }^{9}$; 2) закріплено право осіб, які звільнилися за власним бажанням, отримувати допомогу по безробіттю 31 дня (після звільнення), а не 391 дня, як було раніше; 3) передбачено право всіх безробітних отримувати виплату з 1, а не 37 дня реєстрації, як було раніше ${ }^{10}$; 4) установлено допомоги по частковому безробіттю, у тому числі й виплати суб'єктам малого та середнього підприємництва на період карантину для покриття витрат на зарплату робітникам, яким скорочено робочий час.

Допомога по частковому безробіттю на період карантину надається застрахованим особам у разі втрати ними частини заробітної плати або доходу внаслідок вимушеного скорочення передбаченої законодавством тривалості робочого часу у зв’язку із зупиненням (скороченням) діяльності через проведення заходів щодо запобігання виникненню та поширенню коронавірусної хвороби (COVID-19), передбачених карантином, установленим Кабінетом Міністрів України, за зверненням роботодавця або фізичної особипідприємця, який є застрахованою особою, для ії виплати працівникам або фізичній особі-підприємцю, який є застрахованою особою ${ }^{11}$.

Сума допомоги по частковому безробіттю на період карантину також надається роботодавцям, у тому числі фізичним особам-підприємцям, які є застрахованими особами, із числа суб'єктів малого та середнього підприємництва на строк зупинення (скорочення) діяльності, а також протягом 30 календарних днів після завершення карантину.

Допомога по частковому безробіттю на період карантину надається в разі сплати роботодавцем або фізичною особою-підприємцем, який $\epsilon$ застрахованою особою, ЄСВ протягом шести місяців, що передують даті зупинення діяльності.

На період карантину допомога по частковому безробіттю встановлюється за кожну годину, на яку працівникові або фізичній особі-підприємцю, який $є$ застрахованою особою, скорочено передбачену законодавством тривалість робочого часу. Розмір допомоги визначається виходячи з фінансових можливостей Фонду й не може перевищувати розміру мінімальної заробітної плати.

\footnotetext{
${ }^{8}$ Про мінімальний розмір допомоги по безробіттю на період карантину : Постанова Правління Фонду загальнообов'язкового державного соціального страхування України на випадок безробіття від 8 квітня 2020 p. № 217. База даних «Фонд соиіального страхування Украӥни». URL: https://zakon.rada.gov.ua/laws/ show/z0344-20\#Text (дата звернення: 20.11.2020).

9 Про загальнообов'язкове державне соціальне страхування на випадок безробіття : Закон України від 2 березня 2000 р. № 1533-III / Верховна Рада України. URL: https://zakon.rada.gov.ua/laws/show/ 1533-14\#Техt (дата звернення: 23.11.2020).

${ }^{10}$ Про внесення змін до Закону України «Про державний бюджет України на 2020» : Закон України від 13 квітня 2020 р. № 553-IX / Верховна Рада України. URL: https://zakon.rada.gov.ua/laws/show/553-20\#Text (дата звернення: 23.11.2020).

${ }^{11}$ Про зайнятість населення : Закон України від 5 липня 2012 р. № 5067-VI / Верховна Рада України. URL: https://zakon.rada.gov.ua/laws/show/5067-17\#Text (дата звернення: 23.11.2020).
} 
Виплата допомоги здійснюється 3 першого дня скорочення тривалості їхнього робочого часу в межах строку зупинення (скорочення) діяльності, але не більше ніж 30 календарних днів після завершення карантину.

Роботодавець або фізична особа-підприємець, який $є$ застрахованою особою, може звернутися за отриманням допомоги по частковому безробіттю на період карантину протягом 90 календарних днів 3 дня зупинення (скорочення) виробництва.

Усі вищезазначені зміни щодо виплати допомоги по частковому безробіттю внесені на підставі Закону України «Про внесення змін до Закону України «Про державний бюджет України на 2020 рік» від 13 квітня 2020 року $553-\mathrm{IX}^{12}$.

Необхідно зазначити, що виплата допомог по безробіттю здійснюється Фондом загальнообов'язкового державного соціального страхування на випадок безробіття за рахунок коштів державного бюджету ${ }^{13},{ }^{14}$.

Упровадження на території України карантинних обмежень зумовило внесення змін $\mathrm{i}$ до процедури отримання окремих видів соціального забезпечення, а саме передбачено можливість їх отримання віддалено, без особистого звернення до органів соціального забезпечення.

Загалом усі передбачені зміни можна звести до такого: 1) перепризначення соціальних допомог автоматично; 2) вирішення питань, пов'язаних iз пенсійними виплатами онлайн ${ }^{15}$; 3) спрощення процедури надання житлових субсидій, а саме надання субсидій навіть у тому випадку, якщо особа має заборгованість за комунальні послуги за 3 місяці; установлення заборони припиняти виплату житлових субсидій; призначення субсидій на наступний період автоматично без звернення громадян; установлення заборони нараховувати штрафи й пеню за несплату житлово-комунальних послуг ${ }^{16}$.

\footnotetext{
${ }^{12}$ Про внесення змін до Закону України «Про державний бюджет України на 2020» : Закон України від 13 квітня 2020 р. № 553-IX / Верховна Рада України. URL: https://zakon.rada.gov.ua/laws/show/553-20\#Text (дата звернення: 23.11.2020).

${ }^{13}$ Про виділення коштів для надання фінансової допомоги Фонду загальнообов'язкового державного соціального страхування на випадок безробіття : Постанова Кабінету Міністрів України від 27 квітня 2020 p. № 308. База даних «Законодавство України». URL: https://zakon.rada.gov.ua/laws/show/308-2020\%D0\%BF\#Text (дата звернення: 21.11.2020).

${ }_{14}^{14}$ Про виділення коштів для надання фінансової допомоги Фонду загальнообов'язкового державного соціального страхування на випадок безробіття для здійснення виплат допомоги по безробіттю та допомоги по частковому безробіттю на період карантину :Постанова Кабінету Міністрів України від 28 жовтня 2020 p. № 1040. База даних «Законодавство Украӥни». URL: https://zakon.rada.gov.ua/ laws/show/1040-2020-\%D0\%BF\#Text (дата звернення: 21.11.2020).

15 Про внесення змін до деяких законодавчих актів, спрямованих на забезпечення додаткових соціальних та економічних гарантій у зв'язку з поширенням коронавірусної хвороби (COVID-2019) : Закон України від 30 березня 2020 р. № 540-IX / Верховна Рада України. URL: https://zakon.rada.gov.ua/ laws/show/540-20\#Text (дата звернення: 24.11.2020).

${ }^{16}$ Про особливості надання житлових субсидій : Постанова Кабінету Міністрів України від 25 березня 2020 р. № 247 / Верховна Рада України. URL: https://zakon.rada.gov.ua/laws/show/247-2020-\%D0\%BF\#Text (дата звернення: 24.11.2020).
} 


\section{2. Соціальне забезпечення медичних працівників}

Як показала практика, у боротьбі з COVID-19 найбільшого захисту й соціальної підтримки потребують медичні працівники, які щодня наражають своє здоров'я та життя на небезпеку. Нині кожен п'ятий із хворих медичний працівник. Щоб мотивувати лікарів і медсестер працювати попри небезпеку, держава, окрім гідної заробітної плати, повинна гарантувати їм і членам їхніх сімей належний рівень соціального забезпечення, якщо медичний працівник під час виконання своїх трудових обов'язків захворіє на COVID-19, набуде статусу особи з інвалідністю або взагалі помре.

Із цією метою внесено зміни до переліку професійних захворювань ${ }^{17}$, а саме його доповнено новим професійним захворюванням: гострою респіраторною хворобою COVID-19, спричиненою коронавірусом SARS-CoV-2, і віднесено до переліку особливо небезпечних інфекційних хвороб ${ }^{18}$. Віднесення COVID-19 до переліку професійних захворювань автоматично дало можливість медичним працівникам, які захворіли чи захворіють, отримувати всі види страхових виплат, що передбачені в Законі України «Про загальнообов'язкове державне соціальне страхування», а саме в розділі V «Загальнообов'язкове державне соціальне страхування від нещасного випадку на виробництві та професійного захворювання, які спричинили втрату працездатності».

Процедура встановлення гострого професійного захворювання здійснюється в загальному порядку відповідно до Постанови КМУ «Про затвердження Порядку розслідування та обліку нещасних випадків, професійних захворювань та аварій на виробництві» від 17 квітня 2019 року № $337^{19}$.

Відповідно до Закону України «Про загальнообов'язкове державне соціальне страхування», медичним працівникам допомога по тимчасовій непрацездатності виплачується в розмірі 100 відсотків середньої заробітної плати (доходу) незалежно від страхового стажу, якщо останні перебувають у закладах охорони здоров'я, а також на самоізоляції під медичним наглядом у зв'язку з проведенням заходів, спрямованих на запобігання

17 Про внесення зміни до переліку професійних захворювань : Постанова КМУ від 13 травня 2020 р. № 394. База даних «Законодавство Украӥни». URL: https://zakon.rada.gov.ua/laws/show/394-2020\% D0\%BF\#Text (дата звернення: 24.11.2020).

18 Про внесення зміни до Переліку особливо небезпечних, небезпечних інфекційних та паразитарних хвороб людини і носійства збудників цих хвороб : Наказ Міністерства Охорони Здоров'я України від 25 листопада 2020 р. № 521. База даних «Законодавство України». URL: https://moz.gov.ua/article/ministrymandates/nakaz-moz-ukraini-vid-25022020--521-pro-vnesennja-zmini-do-pereliku-osoblivo-nebezpechnih-

nebezpechnih-infekcijnih-ta-parazitarnih-hvorob-ljudini-i-nosijstva-zbudnikiv-cih-hvorob (дата звернення: 25.11.2020).

19 Про затвердження Порядку розслідування та обліку нещасних випадків, професійних захворювань та аварій на виробництві : Постанова Кабінету Міністрів України від 17 квітня 2019 р. № 337. База даних «Законодавство України». URL: https://zakon.rada.gov.ua/laws/show/337-2019-\%D0\%BF\#Text (дата звернення: 22.11.2020). 
виникненню та поширенню коронавірусної хвороби. Такий вид допомоги здійснюється за рахунок коштів Фонду ${ }^{20}$.

3 метою додаткового захисту медичних працівників Верховною Радою України прийнято Закон України «Про внесення змін до статті 39 Закону України «Про захист населення від інфекційних хвороб» щодо додаткових гарантій прав медичних та інших працівників, зайнятих у сфері захисту населення від інфекційних хвороб, та членів їх сімей» від 7 травня 2020 року № 588-IX. Останнім закріплено право за медичними працівниками, які працюють у державних чи комунальних закладах охорони здоров'я, на отримання страхових виплат у разі встановлення групи інвалідності протягом одного календарного року, що настала внаслідок захворювання на COVID-19, або в разі смерті такого працівника ${ }^{21}$.

Окрім вищезазначеного Закону, паралельно у Верховній Раді розглядалися ще два інші законопроекти: Проект Закону України «Про внесення змін до Закону України «Про захист населення від інфекційних хвороб» (щодо визначення розмірів обов'язкового державного страхування працівників державних і комунальних закладів охорони здоров'я, зайнятих у сфері захисту населення від інфекційних хвороб) від 22 квітня 2020 року № $3376^{22}$ і Проект Закону України «Про внесення змін до Закону України «Про захист населення від інфекційних хвороб» (щодо належного та справедливого соціального захисту медичних та інших працівників, зайнятих у сфері захисту населення від інфекційних хвороб)» від 6 травня 2020 року № 3376-2 23 .

Особливістю вищезазначених законопроектів є те, що вони передбачали здійснення страхових виплат у випадку підтвердження самого факту інфікування незалежно від того було встановлено групу інвалідності чи ні. Прийняття законопроекту такого змісту дало б можливість усім медичним працівникам, які захворіли на COVID-19, отримати страхові виплати, проте

\footnotetext{
${ }^{20}$ Про загальнообов'язкове державне соціальне страхування : Закон України від 23 вересня 1999 р. № 1105-XIV / Верховна Рада України. URL: https://zakon.rada.gov.ua/laws/show/1105-14 (дата звернення: 14.11.2020).

${ }^{21}$ Про внесення змін до статті 39 Закону України «Про захист населення від інфекційних хвороб» щодо додаткових гарантій прав медичних та інших працівників, зайнятих у сфері захисту населення від інфекційних хвороб, та членів їх сімей : Закон України від 7 травня 2020 року № 588-IX / Верховна Рада України. URL: https://zakon.rada.gov.ua/laws/show/588-20\#Text (дата звернення: 20.11.2020).

22 Про внесення змін до Закону України «Про захист населення від інфекційних хвороб» (щодо визначення розмірів обов'язкового державного страхування працівників державних і комунальних закладів охорони здоров’я, зайнятих у сфері захисту населення від інфекційних хвороб) : Проект Закону України від 22 квітня 2020 р. № 3376 / Верховна Рада України. URL: http://w1.c1.rada.gov.ua/pls/zweb2/webproc4 $1 ? \mathrm{pf3511}=68642$ (дата звернення: 23.11.2020).

${ }_{23}$ Про внесення змін до Закону України «Про захист населення від інфекційних хвороб» (щодо належного та справедливого соціального захисту медичних та інших працівників, зайнятих у сфері захисту населення від інфекційних хвороб» : Проект Закону України від 6 травня 2020 р. № 3376-2 / Верховна Рада України. URL: http://w1.c1.rada.gov.ua/pls/zweb2/webproc4_1?pf3511=68767 (дата звернення: 19.11.2020).
} 
в цьому випадку число медичних працівників було б значно більшим порівняно з числом медичних працівників, яким унаслідок захворювання встановлено групу інвалідності, тому з вищезазначеного стає зрозуміло, чому законопроекти так і не прийняті.

На підставі Закону № 588-IX прийнято Постанову КМУ «Деякі питання надання страхових виплат у разі захворювання або смерті медичних працівників у зв'язку 3 інфікуванням гострою респіраторною хворобою COVID-19, спричиненою коронавірусом SARS-CoV-2» від 17 червня 2020 року № 498, якою затверджено Порядок здійснення страхових виплат у разі захворювання або смерті медичних працівників у зв'язку з інфікуванням гострою респіраторною хворобою COVID-19, спричиненою коронавірусом SARS-CoV-2, та визначення їх розмірів.

Якщо провести відповідні розрахунки, то медичному працівникові у випадку встановлення I групи інвалідності буде виплачено 840800 тисяч гривень; у випадку встановлення II групи інвалідності - 735700 тисяч гривень; у випадку встановлення III групи інвалідності - 630600 тисяч гривень. У разі смерті медичного працівника членам сім’і, батькам, утриманцям померлого медичного працівника проводиться виплата в розмірі 750-кратного розміру прожиткового мінімуму для працездатних осіб, що станом на сьогодні дорівнює 1576500 тисяч гривень ${ }^{24}$.

У Постанові КМУ № 498 від 17 червня 2020 року зазначено, що члени сім'ї та батьки померлого медичного працівника визначаються відповідно до положень Сімейного кодексу України, проте в Сімейному кодексі немає законодавчого визначення «член сім'ї». Натомість його можна знайти в статті 64 Житлового кодексу Української РСР (ЖК УРСР); у рішенні Конституційного Суду України від 3 червня 1999 року 5-рп/99 тощо ${ }^{25}$.

Страхові виплати мають разовий характер і здійснюються виключно за рахунок коштів із державного бюджету.

Як зазначалося вище, медичні працівники, окрім страхових виплат, що здійснюються за рахунок коштів державного бюджету, мають право й на отримання страхових виплат, передбачених статтею 36 Закону України «Про загальнообов’язкове державне соціальне страхування».

Тобто в разі підтвердження інвалідності та стійкої втрати працездатності медичному працівнику буде виплачено одноразову допомогу за рахунок коштів державного бюджету й одноразову допомогу у зв’язку зі стійкою

\footnotetext{
24 Деякі питання надання страхових виплат у разі захворювання або смерті медичних працівників у зв'язку з інфікуванням гострою респіраторною хворобою COVID-19, спричиненою коронавірусом SARSCoV-2 : Постанова Кабінету Міністрів України від 17 червня 2020 р. № 498. База даних «Законодавство України» URL: https://zakon.rada.gov.ua/laws/show/498-2020-\%D0\%BF\#Text (дата звернення: 23.11.2020).

25 Рішення Конституційного Суду України від 3 червня 1999 р. 5-рп/99. База даних «Законодавство України». URL: http://zakon3.rada.gov.ua/laws/show/v005p710-99 (дата звернення: 23.11.2020).
} 
втратою працездатності, щомісячні страхові виплати (за рахунок коштів Фонду), остання виплата покликана компенсувати медичному працівнику втрачений заробіток залежно від ступеня втрати працездатності й виплачується кожного місяця до повного відновлення здоров'я або упродовж усього життя потерпілого. У разі смерті медичного працівника буде здійснено страхову виплату (одноразову допомогу) Фондом за рахунок коштів державного бюджету й одноразову допомогу за рахунок коштів Фонду.

\section{ВИСНОВКИ}

Світова пандемія внесла чимало коректив у життя кожної держави, не оминувши практично жодної сфери. Поряд із системою охорони здоров'я важливе місце нині належить системі соціального забезпечення. Якщо для першої основним завданням є боротьба за життя та здоров'я кожної людини в прямому сенсі цього слова, то завданням останньої $\epsilon$ забезпечення належного (соціального) рівня цього життя в кризовий період.

Процес трансформації систем соціального забезпечення в кожній країні відбувався за своєю окремою схемою. В Україні ж основна увага зосереджена на підвищенні рівня соціального забезпечення медичних працівників, які безпосередньо беруть участь у боротьбі з COVID-19, страхові виплати останнім здійснюються за рахунок двох бюджетів одночасно: державного та Фонду соціального страхування України, але лише у тому випадку, якщо в результаті зараження коронавірусною інфекцієї їм буде встановлено відповідну групу інвалідності або у випадку їх смерті. Якщо ж COVID-19 спричинить лише тимчасову непрацездатність, то медичний працівник може розраховувати виключно на допомогу У зв'язку з тимчасовою непрацездатністю. У цьому разі доцільно було надати останнім також право на отримання й додаткових страхових виплат за рахунок коштів державного бюджету, звісно, у зменшеному розмірі, ніж для осіб, яким установлено інвалідність, проте, з іншого боку, це призвело б до збільшення видатків із держбюджету.

Низка змін також стосувалися порядку сплати $\mathrm{CCB}$, процедури отримання окремих страхових виплат, допомог, субсидій, соціального забезпечення безробітних, пенсіонерів, проте можемо констатувати, що у фінансовому співвідношенні вони були вкрай незначними, тому й не дивно, що багато хто громадян не відчув покращення власного матеріального становища.

Проведене дослідження в черговий раз дало можливість пересвідчитися в тому, що рівень соціального забезпечення прямо залежить від фінансових можливостей держави, а особливо в кризові періоди, коли кількість осіб, що зазнали того чи іншого соціального ризику, збільшується в декілька разів. 


\section{АНОТАЦІЯ}

Першочерговим завданням у період пандемії коронавірусної хвороби для всіх держав стало розроблення низки заходів, спрямованих на превенцію та протидію COVID-19. Однією 3 провідних систем, що знаходиться на «передовій» у боротьбі із COVID-19, є система соціального забезпечення кожної країни. За період дії карантинних обмежень в Україні внесено чимало змін у нормативно-правове регулювання вітчизняної системи соціального забезпечення, що зумовило необхідність у здійсненні правового дослідження.

Проведене дослідження дало змогу встановити, які основні зміни внесено в низку нормативно-правових актів і щодо яких категорій населення й надати їм об'єктивну правову оцінку.

Особлива увага приділяється дослідженню внесених змін до порядку сплати ССВ на період карантину, що в результаті призвели до часткового задоволення інтересів платників ССВ та подальшого зменшення коштів державного бюджету; порядку й розмірів допомог по безробіттю, у тому числі й по частковому; підвищення рівня пенсійних виплат; питання соціального забезпечення медичних працівників, як категорії, яка потребує найбільшого захисту та соціальної підтримки.

Зроблено висновок про залежність рівня соціального забезпечення від рівня фінансових можливостей держави, особливо в кризові періоди, коли кількість осіб, що зазнали того чи іншого соціального ризику, збільшується в декілька разів.

\section{ЛІТЕРАТУРА}

1. Про внесення змін до Податкового кодексу України та інших законів України щодо підтримки платників податків на період здійснення заходів, спрямованих на запобігання виникненню i поширенню коронавірусної хвороби (COVID-19) : Законом України від 17 березня 2020 р. № 533-IX / Верховна Рада України. URL: https://zakon.rada.gov.ua/laws/show/533-20\#Text (дата звернення: 18.11.2020).

2. Про внесення змін до Податкового кодексу України та інших законів України щодо додаткової підтримки платників податків на період здійснення заходів, спрямованих на запобігання виникненню і поширенню коронавірусної хвороби (COVID-19) : Закон України від 13 травня 2020 р. № 591-IX / Верховна Рада України. URL: https://zakon.rada.gov.ua/laws/show/591-20\#Text (дата звернення: 18.11.2020).

3. Про внесення змін до деяких законодавчих актів України щодо додаткової підтримки платників податків на період здійснення заходів, спрямованих на запобігання виникнення і поширення коронавірусної хвороби (COVID-19) : Проект Закону України від 9 липня 2020 р. № 3824 / Верховна Рада України. 
URL: http://w1.c1.rada.gov.ua/pls/zweb2/webproc4_1?pf3511=69423 (дата звернення: 19.11.2020).

4. Про внесення змін до Закону України «Про збір та облік єдиного внеску на загальнообов'язкове державне соціальне страхування» : Закон України від 13 травня 2020 р. № 592-IX / Верховна Рада України. URL: https://zakon.rada.gov.ua/laws/show/592-20\#Text (дата звернення: 19.11.2020).

5. Деякі питання підвищення пенсійних виплат і надання соціальної підтримки окремим категоріям населення у 2020 році : Постанова Кабінету Міністрів України від 1 квітня 2020 р. № 251. База даних «Законодавство Украӥни». URL: https://www.kmu.gov.ua/npas/deyaki-pitannya-pidvishchennyapensijnih-viplat-i-nadannya-socialnoyi-pidtrimki-okremim-kategoriyamnaselennya-u-2020-roci-i010420-251 (дата звернення: 19.11.2020).

6. Деякі питання підвищення пенсійних виплат для окремих категорій осіб у 2021 році та в подальшому: Постанова Кабінету Міністрів України від 16 вересня 2020 р. № 849. База даних «Законодавство України». URL: https://www.kmu.gov.ua/npas/deyaki-pitannya-pidvishchennya-pensijnihviplat-dlya-okremih-kategorij-osib-u-2021-roci-ta-v-podalshomu-i160920-849 (дата звернення: 20.11.2020).

7. Ситуація на ринку праці та діяльність Державної служби зайнятості у січні-жовтні 2020 року. Офіџійний сайт Державної служби зайнятості. URL: https://www.dcz.gov.ua/analitics/67 (дата звернення: 23.11.2020).

8. Про мінімальний розмір допомоги по безробіттю на період карантину: Постанова Правління Фонду загальнообов'язкового державного соціального страхування України на випадок безробіття від 8 квітня 2020 р. № 217. База даних «Фонд соиіального страхування України». URL: https://zakon.rada.gov.ua/ laws/show/z0344-20\#Tеxt (дата звернення: 20.11.2020).

9. Про загальнообов'язкове державне соціальне страхування на випадок безробіття : Закон України від 2 березня 2000p. № 1533-III / Верховна Рада України. URL: https://zakon.rada.gov.ua/laws/show/1533-14\#Text (дата звернення: 23.11.2020).

10. Про внесення змін до Закону України «Про державний бюджет України на 2020» : Закон України від 13 квітня 2020 р. № 553-IX / Верховна Рада України. URL: https://zakon.rada.gov.ua/laws/show/553-20\#Text (дата звернення: 23.11.2020).

11. Про зайнятість населення : Закон України від 5 липня 2012 р. № 5067-VI / Верховна Рада України. URL: https://zakon.rada.gov.ua/laws/ show/5067-17\#Text (дата звернення: 23.11.2020).

12. Про виділення коштів для надання фінансової допомоги Фонду загальнообов'язкового державного соціального страхування на випадок безробіття : Постанова Кабінету Міністрів України від 27 квітня 2020 р. 
№ 308. База даних «Законодавство України». URL: https://zakon.rada.gov.ua/ laws/show/308-2020-\%D0\%BF\#Text (дата звернення: 21.11.2020).

13. Про виділення коштів для надання фінансової допомоги Фонду загальнообов'язкового державного соціального страхування на випадок безробіття для здійснення виплат допомоги по безробіттю та допомоги по частковому безробіттю на період карантину : Постанова Кабінету Міністрів України від 28 жовтня 2020 р. № 1040. База даних «Законодавство України». URL: https://zakon.rada.gov.ua/laws/show/1040-2020-\%D0\%BF\#Text (дата звернення: 21.11.2020).

14. Про внесення змін до деяких законодавчих актів, спрямованих на забезпечення додаткових соціальних та економічних гарантій у зв'язку 3 поширенням коронавірусної хвороби (COVID-2019) : Закон України від 30 березня 2020 p. № 540-IX / Верховна Рада України. URL: https://zakon.rada.gov.ua/laws/show/540-20\#Tехt (дата звернення: 24.11.2020).

15. Про особливості надання житлових субсидій : Постанова Кабінету Міністрів України від 25 березня 2020 р. № 247 / Верховна Рада України. URL: https://zakon.rada.gov.ua/laws/show/247-2020-\%D0\%BF\#Text (дата звернення: 24.11.2020).

16. Про внесення зміни до переліку професійних захворювань: Постанова Кабінету Міністрів України від 13 травня 2020 р. № 394. База даних «Законодавство України». URL: https://zakon.rada.gov.ua/laws/show/394-2020$\% \mathrm{D} 0 \% \mathrm{BF} \#$ Text (дата звернення: 24.11.2020).

17. Про внесення зміни до Переліку особливо небезпечних, небезпечних інфекційних та паразитарних хвороб людини і носійства збудників цих хвороб : Наказ Міністерства Охорони Здоров'я України від 25 листопада 2020 р. № 521. База даних «Законодавство України». URL: https://moz.gov.ua/ article/ministry-mandates/nakaz-moz-ukraini-vid-25022020--521-pro-vnesennjazmini-do-pereliku-osoblivo-nebezpechnih-nebezpechnih-infekcijnih-ta-parazitarnihhvorob-ljudini-i-nosijstva-zbudnikiv-cih-hvorob (дата звернення: 25.11.2020).

18. Про затвердження Порядку розслідування та обліку нещасних випадків, професійних захворювань та аварій на виробництві : Постанова Кабінету Міністрів України від 17 квітня 2019 р. № 337. База даних «Законодавство України». URL: https://zakon.rada.gov.ua/laws/show/ 337-2019-\%D0\%BF\#Техt (дата звернення: 22.11.2020).

19. Про загальнообов'язкове державне соціальне страхування : Закон України від 23 вересня 1999 р. № 1105-XIV / Верховна Рада України. URL: https://zakon.rada.gov.ua/laws/show/1105-14 (дата звернення: 14.11.2020).

20. Про внесення змін до статті 39 Закону України «Про захист населення від інфекційних хвороб» щодо додаткових гарантій прав медичних та інших працівників, зайнятих у сфері захисту населення від 
інфекційних хвороб, та членів їх сімей : Закон України від 7 травня 2020 року № 588-IX / Верховна Рада України. URL: https://zakon.rada.gov.ua/ laws/show/588-20\#Text (дата звернення: 20.11.2020).

21. Про внесення змін до Закону України «Про захист населення від інфекційних хвороб» (щодо визначення розмірів обов'язкового державного страхування працівників державних i комунальних закладів охорони здоров'я, зайнятих у сфері захисту населення від інфекційних хвороб) : Проект Закону України від 22 квітня 2020 р. № 3376 / Верховна Рада України. URL: http://w1.c1.rada.gov.ua/pls/zweb2/webproc4_1?pf3511=68642 (дата звернення: 23.11.2020).

22. Про внесення змін до Закону України «Про захист населення від інфекційних хвороб» (щодо належного та справедливого соціального захисту медичних та інших працівників, зайнятих у сфері захисту населення від інфекційних хвороб : Проект Закону України від 6 травня 2020 р. № 3376-2 / Верховна Рада України. URL: http://w1.c1.rada.gov.ua/pls/zweb2/ webproc4_1?pf3511=68767 (дата звернення: 19.11.2020).

23. Деякі питання надання страхових виплат у разі захворювання або смерті медичних працівників у зв'язку з інфікуванням гострою респіраторною хворобою COVID-19, спричиненою коронавірусом SARS-CoV-2 : Постанова Кабінету Міністрів України від 17 червня 2020 р. № 498. База даних «Законодавство України». URL: https://zakon.rada.gov.ua/laws/show/ 498-2020-\%D0\%BF\#Text (дата звернення: 23.11.2020).

24. Рішення Конституційного Суду України від 3 червня 1999 р. 5-рп/99. База даних «Законодавство України». URL: http://zakon3.rada.gov.ua/laws/ show/v005p710-99 (дата звернення: 23.11.2020).

\section{Information about authors:} Bodnaruk M. I., LL.D., Professor at the Department of Private Law Yuriy Fedkovych Chernivtsi National University

2, Kotsyubynsky str., Chernivtsi, Ukraine

Burka A. V., Ph.D., Assistant at the Department of Private Law Yuriy Fedkovych Chernivtsi National University 2, Kotsyubynsky str., Chernivtsi, Ukraine 